\title{
KERJA PEGAWAI BAGIAN PERLENGKAPAN DAN UMUM DI RUMAH SAKIT ADE MOHAMMAD DJOEN SINTANG
}

\author{
Nikodimus, Abang Zainudin \\ Fakultas Ilmu Sosial dan Ilmu Politik Universitas Kapuas Sintang \\ Email :nangabayan@gmail.com
}

\begin{abstract}
Abstrak: Penelitian ini bertujuan untuk melakukan analisis, deskripsi dan menjelaskan secara mendalam tentang bagaimana kinerja Pegawai Bagian Perlengkapan dan Umum di Rumah sakit Ade Mohammad Djon Sintang. berbagai aspek yang terkait dengan permasalahan Kinerja, Tanggung Jawab, Komunikasi. Penelitian ini mengacu pada sifat-sifat penelitian kualitatis dan deskriptif. Beberapa subjek penelitian yang telah ditentukan sebagai informan atau narasumber Direktur Rumah Sakit Ade Mohammad Djon Sintang, Kepala Bagian Perelngkapan dan umum Rumah Sakit Ade Mohammad Djon Sintang. Hasil penelitian menunjukkan bahwa kinerja pegawai bagian umum dan perlengkapan di Rmuah Sakit Ade Mohammad Djon Sintang masih belum optimal, namum beitu berbagai upaya yang dilakukan pihak rumah sakit terutama di bagian Umum dan perlengkapan terus berbenah untuk mengoptimalkan bidang pelayanan kepada masyarakat. Di samping itu di sarankan kepada pihak Rumah Sakit Ade Mohammad Djon Sintang terus mengawasi kinerja bawahannya.
\end{abstract}

Kata Kunci: Kinerja, Sumber Daya manusia, Motivasi

\section{Pendahuluan}

Pelayanan publik sebagai segala bentuk jasa pelayanan, baik dalam bentuk barang publik maupun jasa publik yang pada prinsipnya menjadi tanggung jawab dan dilaksanakan oleh instansi pemerintah pusat ataupun daerah dalam rangka upaya pemenuhan kebutuhan masyarakat maupun dalam rangka pelaksanaan ketentuan peraturan perundang-undangan. Seiring dengan penerapan sistem desentralisasi. Kemampuan yang dimiliki oleh pegawai akan menunjang tugas atau pekerjaan yang dilaksanakan akan mencapai hasil yang maksimal. Dalam hal ini pegawai negeri sipil sangat perlu dipupuk dan dipelihara kemampuan yang baik, karena apabila pegawai negeri sipil itu tidak tidak memiliki kemampuan dalam pelaksanaan pekerjaannya maka akan menghambat pelaksanaan tugas yang diberikan, juga menimbulkan akibatakibat yang buruk terhadap negara dan masyarakat.

Penilaian yang baik terhadap penghargaan pimpinan kepada bawahannya karena proses pemerintahan yang dibangun selama satu tahun penghargaan terhadap bawahannya sangat terbuka dan cenderung sangat dekat dan lebih mengutamakan etos kerja dibandingkan dengan budaya-budaya birokrasi yang kebanyakan yaitu lebih menjaga wibawa dibandingkan dengan etos dan kualitas kinerja pemerintahan. Etika penghargaan terhadap bawahannya baik maka tentu saja akan terjadi hubungan timbal balik dimana bawahan akan lebih menghargai atasannya, sehingga dengan sendirinya akan muncul motivasi kerja yang

lebih professional dan akuntabilitas bawahan dalam menyelesaikan seluruh proses kinerja pada masingmasing bidang. Ini mengarah pada suatu konsepsi bahwa kemampuan yang dipunyai seorang aparat ditunjukkan dengan kesanggupannya sesuai dengan tingkat pengetahuannya dan keterampilan yang diperolehnya melalui pendidikan dan pengalamannya. Tersedianya modal pengetahuan dan keterampilan inilah yang merupakan salah satu faktor untuk mempertimbangkan penempatan seorang calon pegawai, modal ini biasanya dimiliki oleh mereka yang berpendidikan. Untuk mengukur indikator sumber daya aparat kelurahan, menggunakan 2 sub indikator yaitu Tingkat Pendidikan, dan pengalaman kerja Dalam melaksanakan tugas dan tanggung jawabnya sebagai pegawai khususnya dalam memberikan pelayanan umum kepada masyarakat. Di RS sintang sangat ditentukan oleh tingkat pendidikan yang dimiliki oleh pegawai itu sendiri, olehnya itu semakin berat atau meluasnya tanggung jawab pegawai yang harus dilaksanakan maka dibutuhkan aparat yang memiliki sumber manusia yang berkualitas pula.

Dalam mengembangkan praktik good governance, pemerintah perlu mengambil dan menggunakan strategi yang tepat. Luasnya cakupan persoalan yang dihadapi, kompleksitas dari setiap persoalan yang ada, serta keterbatasan sumberdaya dan kapasitas pemerintah dan juga non-pemerintah 
untuk melakukan pembaharuan praktik governance, mengharuskan pemerintah mengambil pilihan yang strategis dalam memulai pengembangan praktik good governance. Salah satu pilihan strategis untuk mengembangkan good governance di Indonesia adalah melalui pengembangan penyelenggaraan pelayanan publik yang mencirikan nilai-nilai yang selama ini melekat pada good governance. Pelayanan publik menjadi titik strategis untuk memulai pengembangan good governance di Indonesia karena pelayanan publik selama ini menjadi ranah dimana negara yang diwakili oleh pemerintah berinteraksi dengan lembaga-lembaga non-pemerintah. Dalam ranah ini terjadi suatu interaksi yang sangat intensif antara pemerintah dengan warganya. Buruknya praktik governance dalam penyelenggaraan pelayanan publik sangat dirasakan oleh warga dan masyarakat luas. Ini berarti jika terjadi perubahan yang signifikan pada ranah pelayanan publik dengan sendirinya dapat dirasakan manfaatnya secara langsung oleh warga dan masyarakat luas.

Rumah Sakit Ade Muhammad Djoen Sintang salah satu rumah sakit yang ada di Kabupaten Sintang yang memberikan proses pelayanan kepada masyarakat di bidang kesehatan. Namun pada tataran pelaksanaan masih banyak kendala yang dialami ketika dalam melaksanakn Tugas dan fungsi dibidang pelayanan kesehatan. Dalam konteks Undang - undang No. 25 tahun 2009 tentang pelayanan publik disebutkan bahwa standar pelayanan adalah tolak ukur yang dipergunakan sebagai pedoman penyelenggaraan pelayanan dan acuan penilaian kualitas pelayanan sebagai kewajiban dan janji penyelenggara kepada masyarakat dalam rangka pelayanan yang berkualitas, cepat, mudah, terjangkau dan terukur. Bentuk pelayanan dibedakan kedalam beberapa jenis, yaitu: 1) Pelayanan administratif yaitu pelayanan yang menghasilkan berbagai bentuk dokumen resmi yang dibutuhkan oleh publik, misalnya status kewarganegaraan, sertifikat kompetensi, kepemilikkan atau penguasaan terhadap suatu barang dan sebagainya termasuk di dalamnya dokumen-dokumen seperti Kartu Tanda Penduduk, Kartu keluarga. 2) Pelayanan barang yaitu pelayanan yang menghasilkan berbagai bentuk / jenis barang yang digunakan oleh publik misalnya jaringan telepon, penyediaan tenaga listrik dan sebagainya. 3) Pelayanan jasa yaitu pelayanan yang menghasilkan berbagai bentuk jasa yang diperlukan oleh publik misalnya pendidikan, pemeliharaan kesehatan dan lain sebagainya.
Kemampuan yang relatif baik juga harus disejalankan dengan pendidikan khusus atau kecakapan tambahan (kemampuan teknis fungsional) agar mereka mampu bekerja secara teknis sesuai dengan kebutuhan yang ada di dalam pekerjaan. Menurut Hasibuan (2005:94) kemampuan kerja adalah suatu hasil kerja yang dicapai seseorang dalam melaksanakan tugas-tugas yang dibebankan kepadanya yang didasarkan atas kecakapan, pengalaman, dan kesungguhan serta waktu. Disampin itu selain meningkatkan kemampuan tetnu harus ada motivasi dalam melaksanakan pelayanan.

Menurut Mangkunagara (dalam Munandar, 2010) motivasi dapat dipandang sebagai suatu ciri yang ada pada setiap calon tenaga kerja ketika diterima masuk kerja pada suatu perusahaan atau organisasi. Hal ini sangat mendukung karena adanya definisi motivasi kerja adalah suatu kondisi yang berpengaruh untuk meningkatkan, mengarahkan, dan memelihara perilaku yang berhubungan dengan lingkungan kerja.

Keberadaan suatu organisasi akan lebih efektif sangat tergantung dari kemampuan pegawai atau sumberdaya manusia yang ada, untuk itu disamping pendidikan formal pegawai pada di RS juga dituntut meningkatkan kemampuan melalui pendidikan teknis tambahan sebagai suatu keahlian yang harus dimiliki. Rendahnya kemampuan pegawai dalam melaksanakan tugas pokok dan fungsinya mencerminkan pula rendahnya kualitas pegawai yang berdampak pada kurang efektifnya organisasi pelayanan yang ada di RS Sintang. Beberapa fenomena atau gejala-gejala dapat dilihat dari di Rumah Sakit Ade muhamad Djon Sintang yaitu : 1) Masih kurangnya koordinasi antar sesama pegawai dalam melaksanakan pekerjaan. Hal ini dapat dilihat antara pegawai terkadang tidak dapat bekerjasama dengan baik seperti ketika pimpinanmemberikan informasi lewat pegawai tentang tugas yang harus diselesaikan tetapi tidak disampaikan dengan pegawai yang lain. 2) Didalam melaksanakan pekerjaan pegawai kurang menguasai bidang kerjanya. Ini dapat dilihat dari masih ada pegawai di rumahsakit yangbelummemahamitugasdanfungsinya. 3) Tidak pernah diadakannya pelatihan sehubungan dengan pekerjaan yang diberikan. Seperti pelatihan khusus dalam memberikan pelayanan prima kepada masyarakat.

\section{Metode Penelitian}


Desain Penelitian yang digunakan yaitu deskriptif analisis yang berupaya menggambarkan kondisi yang terjadi berdasarkan kenyataan apa adanya. Populasi penelitian yaitu beberapa pegawai yang di bagian umum dan perlengkapan di Rmuah Sakit Ade Muhamad Djon Sintang, Sedangkan sampel penelitian yaitu beberapa orang dari populasi yang dianggap dapat mewakili yaitu: 1) Kepala Bagian Umum dan Perlengkapan (Key Informant), dipilih karena yang bersangkutan menguasai informasi dan persoalan yang sedang diteliti. 2) Pegawai yang di bagian Umum dan Perlengkapan.

Instrumen penelitian yang digunakan yaitu: Pedoman wawancara, yaitu suatu daftar pertanyaan yang telah disusun sebelumnya, yang bersifat pertanyaan-pertanyaan pokok untuk mendapatkan data atau keterangan dari subyek penelitian. Sebelum melakukan penelitian peneliti membuat daftar pertanyaan yang kemudian menjadi pedoman untuk bertanya kepada sampel penelitian sehingga akan diperoleh gambaran dari jawaban yang sesuai dengan konteks pertanyaan yang diajukan. Setelah itu peneliti mengklasifikasikan berbagai jawaban yang relevan dengan penelitian agar tersusun secara sistemtis, setelah itu peneliti menginterpretasikan jawaban dari sampel penelitian tersebut menjadi kalimat-kalimat yang sesuai dengan kaidah dalam karya ilmiah. Panduan Observasi, yaitu pedoman yang digunakan dalam rangka memperoleh data dan informasi yang belum terjaring melalui wawancara, sekaligus mengecek kebenaran informasi dari responden dan informan. Dalam proses observasi tersebut peneliti membuat panduan pengamatan dengan berbagai kriteria berdasarkan pada tujuan penelitian agar dapat dengan mudah memperoleh data-data pengamatan setelah itu data-data hasil pengamatan di deskripsikan ke dalam kalimatkalimat yang sesuai dengan konteks penelitian.Teknik pengumpulan data dengan cara wawancara dan observasi. Menurut Sugiono (2014:85) analisis deskriptif adalah usaha untuk menyederhanakan sekaligus menjelaskan bagian dari keseluruhan langkah-langkahklasifikasi dan kategori sehingga dapat tersusun suatu rangkaian deskripsi yang sistematis sehingga memperoleh suatu kesimpulan.Proses kategorisasi dan klasifikasi data dilakukan secara bertahap atas informasi para informan, serta hasil observasi ketika berada dilapangan dan kemudian dilakukan interpretasi data dalam kerangka teori dan pandangan konseptual yang telah ditentukan sesuai rencana.

Langkah terakhir yaitu penafsiran data, sebagaimana dikemukakan Moleong (2002:199-
200), diterapkan dua langkah yaitu : (a). Menentukan kategori dan kawasannya, yang bermakna mengelompokan data-data dari informan yang sesuai dengan aspek-aspek penelitian. (b). Interogasi terhadap data, yang bermakna mengajukan seperangkat pertanyaansehingga dapat mengungkapkan banyak persoalan dari data itu sendiri berdasarkan hasil interogasi data tersebut, dapat diketahui apakah data yang telah terkumpul tersebut sudah sesuai dengan masalah yang diteliti atau belum untuk mengungkapkan permasalahan sehingga dapat diinterpretasikan sampai dimana data dan informasi yang telah (atau belum) mendukung.Data primer dan data sekunder sebagai pendukung tersebut selanjutnya dianalisis berdasarkan pada katregori-kategori yang berhubungan dengan tujuan yang ingin diperoleh.

\section{HASIL DAN PEMBAHASAN}

\section{Deskripsi Objek Penelitian}

Kabupaten Sintang merupakan salah satu daerah yang terletak dibagain timur propinsi Kalimantan Barat dengan ibukotanya Sintang. Kabupaten Sintang dengan Luas $21.638 \mathrm{~km} \mathrm{2,}$ menempati posisi strategis baik dalam kontek Nasional, Regional dan Internasional. Kabupaten Sintang yang secara administratif berbatasan langsung dengan Serawak (Malaysia Timur) serta berlanjut ke Brunai Darussalam berpotensi menjadi gerbang keluar masuk barang dan orang (outlet) dari dan Serawak maupun Brunai Darussalam melalui jalan darat. Kawasan perbatasan yang ada di Kabupaten Sintang meliputi kecamatan Ketunggau Hilir, Ketunggau Tengah dan Ketunggau Hulu dengan luas kawasannya 586.510 ha atau 18,17\% luas wilayah Kabupaten Sintang dengan panjang perbatasan kurang lebih $143 \mathrm{~km}$.

Ditinjau dari konteks Regional, Kabupaten Sintang terletak pada jalur pelayaran sungai besar yang dilalui dua sungai yaitu Sungai Kapuas dan Sungai Melawi. Selain itu daerah ini berada di jalur jalan lintas Pontianak-Putussibau yang merupakan urat nadi perekonomian Kalimantan Barat. Selain itu jalan darat yang menjadi jalan protokol penghubung beberapa Kabupaten yaitu kabupaten Kapuas Hulu dan juga Kabupaten Melawi melewati wilayah Kabupaten Sintang Sehingga potensi Kabupaten Sintang sebagai sentral perekonomian sangat strategis, oleh karena itu pembangunan sebagai tolak ukur bagi sutau daerah dalam meningkatkan kesejahteraan masyarakat harus mendapat perhatian yang serius baik dari pemerintah propinsi maupun dari pemerintah pusat.

Kemampuan tergantung pada keterampilan dan pengetahuan (ability depends upon both skill and knowledge): dua unsur yaitu pengetahuan dan 
keterampilan merupakan pencerminan dari kemampuan yang diperoleh dari pendidikan formal, informal dan non formal yang dapat menunjang peningkatan kecakapan. Melalui pendidikan akan membentuk dan menambah pengetahuan seseorang untuk mengerjakan sesuatu dengan lebih cepat dan tepat".Masih kurangnya koordinasi antar sesama pegawai dalam melaksanakan pekerjaan. Hal ini dapat dilihat antara pegawai terkadang tidak dapat bekerjasama dengan baik seperti ketika pimpinan memberikan informasi lewat pegawai tentang tugas yang harus diselesaikan tetapi tidak disampaikan dengan pegawai yang lain dalam melaksanakan pekerjaan pegawai kurang menguasai bidang kerjanya. Ini dapat dilihat dari masih ada pegawai di Rumah Sakit Ade Muhammad Djoen Sintang ketika masyarakat bertanya tentang salah satu pengurusan surat menyurat serta keperluan lainnya.

Pegawai negeri sipil sebagai aparatur Negara mempunyai peranan dan fungsi yang sangat penting dalam pemberian pelayanan kepada masyarakat, hal ini tentu saja mensyaratkan agar setiap pegawai harus mempunyai kemampuan kerja yang tinggi, terampil, punya keahlian dan sikap yang baik serta mampu untuk melaksanakan misi, visi, dan menyelenggarakan tugas dan fungsi organisasi serta menjalankan aktifitas operasional organisasi yang menjadi tanggung jawabnya dengan baik, semua ini ditujukan agar pegawai menjadikan pelayanan yang optimal kepada masyarakat. Untuk itu perlu dilakukan upaya perbaikan dan peningkatan kemampuan aparatur Negara agar tercipta aparatur pegawai negeri sipil yang berkualitas, efesien, dan profesional. Hal ini juga sejalan dengan perubahan-perubahan yang terjadi sebagai hasil dari pembangunan dan sebagai akibat dari perubahan eksternal pada tingkat regional dan global. Bahkan kecendrungan umum dalam perubahan ekonomi juga melahirkan tuntutan mengenai perlunya pegawai negeri sipil yang lebih profesional, terampil, terbuka dan berorientasi kepada pelayanan masyarakat

Kemampuan yang dimiliki oleh pegawai akan menunjang tugas atau pekerjaan yang dilaksanakan akan mencapai hasil yang maksimal. Dalam hal ini pegawai negeri sipil sangat perlu dipupuk dan dipelihara kemampuan yang baik, karena apabila pegawai negeri sipil itu tidak tidak memiliki kemampuan dalam pelaksanaan pekerjaannya maka akan menghambat pelaksanaan tugas yang diberikan, juga menimbulkan akibatakibat yang buruk terhadap negara dan masyarakat. Kemampuan Kerja merupakan suatu karakter yang dimiliki seseorang atau yang diperoleh melalui belajar, yang menyebabkan seseorang dapat melakukan sesuatu secara mental atau fisik. Kemampuan berkenaan dengan kapasitas setiap orang untuk melakuakan beberapa tugas dalam suatu pekerjaan. Kemampuan juga adalah penilaian terhadap pekerjaan yang dilakukan.
Dalam konteks pemerintahan daerah, di era otonomi luas di tuntut adanya keterbukaan, akuntabilitas, ketanggapan, dan kreatifitas dari segenap jajaran pegawai yang ada di Rumah Sakit Ade Muhammad Djoen Sintang. Dalam dunia yang penuh dengan kompetitif, sangat diperlukan kemampuan birokrasi dan sumber daya pegawai untuk memberikan tanggapan atau responsive terhadap berbagai tantangan secara akurat, bijaksana, adil dan efektif. PNS di Rumah Sakit Ade Muhammad Djoen Sintang yang mengisi wadah sekaligus melaksanakan rangkaian kegiatan pemerintah di tingkat kecamatan adalah manusia, padahal manusia adalah mahkluk hidup yang mempunyai perilaku (bihavior) maka dengan sendirinya kinerja pemerintah kecamatan itu banyak tergantung pada perilaku manusia (PNS) yang terdapat didalamnya. Dari uraian tersebut diketahui bahwa faktor kemampuan sumber daya manusia (PNS) yang berpengaruh terhadap kinerja pemerintah di Rumah Sakit Ade Muhammad Djoen Sintang.

Kinerja Pegawai Rumah Sakit Ade Muhammad Djoen Sintang Satu masih kurang nampak dalam melakukan proses pelayanan. hal ini terlihat pada serana peunjang pegawai yang melakasankan perkerjaan di RS Sintang. Terlihat bahwa sarana dan prasarana yang masih kurang, hanya terdapat beberapa kursi, meja, lemari dan peralatan kantor lainnya terutama peralatan untuk pelayanan kepada masyarakat. Mejadi tolak ukur dalam melakukan pelayanan kepada masyarakat kalau tidak di tunjang sarana dan prasarana yang memadai di sebuah perkantoran terutama di Rumah Sakit Ade Muhammad Djoen Sintang.

Pegawai yang ada di Rumah Sakit Ade Muhammad Djoen Sintang, diketahui bahwa dukungan kinerja pegawai masih kurang terutama dalam bentuk pelayanan kepada masayarakat. Hal ini di sebebkan salah satu faktor ialah tingkat kemampuan dan pengetahuan pegawai tersebut yang masih kurang memahami proses administrasi, terutama dalam bentuk administrasi pelayanan kepada masyarakat.

\section{Daftar Pustaka}

Hasabuan S.P Manyu (2005) Manajemen Sumber Daya manusia. Edisi revisi Jakarta: Bumu Akrasa

Moleong, Lexy. (2002). Metodologi Penelitian Kualitatif. Bandung: PT. remaja Rosdakarya.

Munandar, M. 2010. Budgeting Perencanaan Kerja Pengkoordinasian Kerja Pengawasan Kerja. Yogyakarta : BPFE

Sugiyono. (2014). Metode Penelitian Pendidikan Pendekatan Kuantitatif, Kualitatif, dan R\&D. Bandung: Alfabeta 